\title{
Agroindustry Business Analysis of Ilham Creativepreneur Nature Kerinci (ICN Kerinci) Coffee Perfume in Kemantan Village, Kerinci Regency, Jambi Province, Indonesia
}

\author{
Zelfi Zakir, Sri Wahyuni, Faidil Tanjung \\ * Lecturer in Social Economics Department, Faculty of Agriculture, Andalas University, Padang
}

\section{ARTICLE INFORMATION}

Article history:

Received:

Revised:

Accepted:

Keywords:

Coffee Perfume, Profit, Break Even

Point.

Correspondence:

\section{A B S T R A C T}

This study aims to analyze the ICN Kerinci Coffee Perfume agroindustry. Data collected from June 2019 to August 2019 were analyzed using the descriptive analysis to describe the business profile and quantitative analysis using the variable costing approach to explore profit and breakeven point. The results showed that the ICN Kerinci coffee perfume business is a medium-scale business with ten workers, including business owners as leaders who concurrently marketers and wives as administrative and financial staff. In fulfilling raw materials in green beans from the Robusta type, business owners collaborate with partner farmers. At the time of research, ICN Kerinci only produced one kind of product with two packaging variants, namely Kerinci original perfume for Rp.22,000/pack (45 grams) and an original variant + oil coffee (package) for Rp.35,000/pack. The study suggested expanding the market, especially to Eastern Indonesia, and increasing good cooperation with farmers to ensure the certainty of supply of raw materials; and provide prices based on sorting and grading to stimulate farmers to improve the quality of their green bean products.

(C)2020

\section{INTRODUCTION}

\section{Background}

Coffee is one of the mainstay commodities in the plantation sub-sector of many countries globally, mainly because the coffee consumption trend of various groups is increasing. Based on data from the International Coffee Organization (ICO), the global produced approximately 9 million tons of coffee in 2016, in which about $36 \%$ or 3.3 million tons of production in Brazil as the largest coffee producer in the world, followed by
Vietnam 1,53 million tons of coffee and Colombia as much as 840 thousand tons of coffee.

Indonesia is one of the largest coffee producers in the world after Colombia, occupying the fourth position according to the 2016 ICO data. Indonesia has produced as many as 600 thousand tons with a percentage of $6,6 \%$ of the total worldwide coffee production. It makes coffee one of the primary commodities in the plantation sector. The role of coffee commodities in the Indonesian economy, among others, is as one source of foreign exchange, employment providers, and a source of income for coffee farmers and other economic actors 
involved in the processing and marketing chain. Indonesia's coffee production is partially exported to foreign countries spanning five continents, Asia, Africa, Australia, America, and Europe, with a significant share in Europe. The rest is marketed in the country. In 2016, the top five import countries in Indonesia were the United States, Germany, Malaysia, Italy, and Russia (BPS, 2017 ).

In 2017, Indonesia's total area of coffee plantations was 1,251,703 hectares (BPS, 2017). Jambi Province is one of the leading coffee-producing regions in Indonesia, with a plantation area of 26,847 hectares and a total production of 13,395 tons in 2016. In 2017, coffee plantations increased to 27,446 hectares with a total output of 14,034 tons. This data shows that coffee potential in Jambi is very promising ( BPS, 2017).

As one of the commodity-producing sources of foreign exchange, which plays an essential role in developing the plantation industry, the coffee business has various obstacles due to the excess coffee beans (Lestari, 2013). It can indirectly be an opportunity to develop the downstream coffee industry to anticipate the saturation of the coffee bean market and increase value-added.

One diversification of coffee products by our people which recently began to develop is the Kerinci Coffee Perfume. As the name implies, the coffee perfume comes from Kerinci Regency, Jambi Province. So far, these coffee products are sold by farmers to traders and sold to local coffee processors to be processed into ground coffee, which can be used as souvenirs from Kerinci Regency and Tea Kayuaro.

A start-up business often faces several problems, both technical problems, and non-technical problems. Nontechnical issues include high cost of capital and investment in coffee processing, fluctuation in output and input prices, the highest risk, and interest rates. (Romdhon , Andani , \& Ayu , 2018).

The various problems mentioned above, especially regarding the lack of planning policies and business and market strategies and the lack of orderliness of the bookkeeping process carried out, make business challenging to develop. Therefore, it is necessary to design a business plan and strategy, in this case of the coffee perfume business, both from financial and market aspects, to anticipate various obstacles that often arise along with the business development that will be carried out.

\section{Statement of Problems}

Jambi Province is one of the coffee production centers that produce the highest quality coffee in Indonesia. Still, farmers can only sell in the form of cherry, which requires further processing to be used as raw material for drinks and snacks. This condition causes farmers to vary depending on the traders in selling their coffee production.

With the development of processing technology, coffee can be processed into ground coffee as a beverage and comestible ingredients. It can also be used as a raw material for perfume because of the essential oil content in oil coffee. Coffee farmers have not felt the benefits of this processing technology. The low price of coffee beans received by farmers is only IDR 8,000 / kg cherry. This condition encourages Mr. Gunaryadi to increase the price at farmgate by opening a coffee processing business for coffee perfume and making cooperation (partnering) with farmers as a supplier of raw materials since early 2019 under the name of Ilham Creative Preneur Kerinci (ICN Kerinci) Coffee Perfume business.

As a new business, there are still many obstacles encountered. The company owner works alone and has his management style (all managerial functions such as marketing, finance, and administration) and does not feel the need for feasibility studies, market research, and other financial performance that is indispensable for business activities. Based on these problems, the authors feel the need to study business feasibility and marketing based on marketing mix conditions run by business owners.

The purposes of this research are to:

1. Describe the profile of Ilham Creative Preneur Nature Kerinci (ICN Kerinci) coffee perfume business

2. Analyzing the feasibility of ICN Kerinci coffee perfume business in terms of economic and market aspects

\section{MATERIALS AND METHODS}

This research was carried out in the Ilham Creative Preneur Nature (ICN) Kerinci Coffee Perfume 
Agroindustry business in Kemantan Village, East Air Hangat District, Kerinci Regency, Jambi Province, which used a descriptive method with a case study approach. Collecting data in this study was using direct observation techniques through direct interviews with relevant parties, namely leaders, employees of the production, marketing, and packing and farmers two partners each.

Analysis tools used in research are:

1. Regarding the Kerinci coffee perfume profile description, data analysis on the business and market profile will be performed descriptively (Natsir, 2005).

2. Regarding the Kerinci coffee perfume business's feasibility analysis, the data will be analyzed quantitatively using a cost accounting approach through the Variable Costing method. The variable Costing Approach is a method of determining the cost of products based on variable cost behavior and fixed costs.

By using the following formula:

1. Analysis of profit (profit/loss)

Profit or net profit can be seen from the difference between sales revenue and all costs for the period June 2019 to August 2019.

Profit formula:

$\pi=\mathrm{TR}-\mathrm{TC}$

$\pi=$ profit $(\mathrm{Rp})$

$\mathrm{TR}=$ Total Revenue $(\mathrm{Rp})$

$\mathrm{TC}=$ Total cost $(\mathrm{Rp})$

Revenue Formula :

$\mathrm{TR}=\mathrm{Y} . \mathrm{P}$

$\mathrm{Y}=$ Number of products sold (print)

$\mathrm{P}=$ Selling price per unit (Rp/print)

Rumus Biaya Total:

$\mathrm{TC}=\mathrm{FC}+\mathrm{VC}$

$\mathrm{FC}=$ Fixed Cost $(\mathrm{Rp})$

$\mathrm{VC}=$ Variable Cost $(\mathrm{Rp})$

2. Calculation of depreciation costs
The amount of depreciation and equipment costs can be calculated using the straight-line method, using the formula:

$\mathrm{D}=(B-S) / N$

Where: $\mathrm{D}=$ Number of annual depreciation

$\mathrm{B}=$ The purchase price of the asset

$\mathrm{S}=$ Residual Value

$\mathrm{N}=$ Age of Economic Assets (Ibrahim, 2009)

3. Profitability

Profitability is one of the factors that determine the high and low of business performance and is a comparison between profits from sales with total costs expressed with a percentage of profitability ratios can be formulated as follows

Profitability $=(\pi / T C) \times 100 \%$

Where:

$\pi=$ profit

$\mathrm{TC}=$ Total Cost

\section{Break Even Point Analysis (BEP)}

BEP can be calculated in two ways, namely:

Break Even Point (BEP) of Selling Price Unit

a. Break Even Point (BEP) of Selling Price Unit

BEP Unit $=\frac{F C}{P-V C}$

b. Break Even Point (BEP) Rupiah

$B E P$ Rupiah $=\frac{F C}{1-\frac{V C}{T R}}$

Notes :

$\mathrm{BEP}=$ Break Even Point

$\mathrm{Q}=$ Quantities (Production)

$\mathrm{FC}=$ Fixed Cost

$\mathrm{VC}=$ Variable Cost

$\mathrm{P}=$ Price 


\section{RESULTS AND DISCUSSION}

\section{Business profile of Ilham Creative Preneur Nature Kerinci (ICN Kerinci) coffee perfume industry}

The ICN Kerinci coffee perfume was founded by Mr. Gunaryadi in early January 2019, but routine production activities only began in February 2019. This business was the first attempt to process coffee into coffee perfume in Kerinci Regency, so that the description of the coffee perfume agroindustry was only depicted based on ICN Kerinci coffee perfume and having its address in the village of Kemantan, Kecamatan East Air Hangat, Kerinci Regency, Jambi Province.

ICN Kerinci coffee perfume has ten employees, including business owners and wives in the production and packing section, while the business owner is the leader who also doubles as marketing manager and wife in administration and finance. This industry produces between 10-15 times a month. Salaries or wages are given differently for each section; the administration is given a salary of Rp. 3,500,000 / month. While the production and packing part is based on the items produced.

At the time of the study, there were two product variants, namely original coffee perfume and original coffee perfume + oil coffee package. The main raw material for the ICN Kerinci Coffee Perfume industry is green bean coffee obtained from partner farmers who manage 25 ha of land. For the 1x production process, 75 $\mathrm{kg}-80 \mathrm{~kg}$ of green bean coffee is needed, and from $1 \mathrm{x}$, the production process produces 1100 original coffee perfume packages and 400 packages containing 400 original coffee perfume packages +400 bottles of coffee oil.

The coffee perfume production process is conducted every day except Sundays or holidays. Activities carried out starting from 8:00 a.m. until 4:00 p.m. For one time, the production process takes two days so that in one month, the average production activity is carried out 12 times, except when demand increases, as in August, the production activity is carried out 14 times.

Marketing of products is done through online media such as Facebook and Instagram. After the agreement with the buyer, the product is shipped by courier such as JNE and JNT to the outside areas of Sumatra, while the marketing area in Sumatera through inter-city transportation. According to Kotler (1994), this marketing system is called a direct marketing system that is more effective and efficient.

For the shipping costs, the following conditions apply. 1) if the purchase is $\leq 50$ packs, marketing costs are borne by the buyer, 2) if the purchase $=100$ packs, the cost is borne $50 \%$ by the business party and $50 \%$ by the buyer, 3 ) if the purchase is $>100$ packs, the shipping fee is $100 \%$ borne by the owner effort. Where the cost of shipping every 100 packs of coffee perfume for buyers who are in the region of Sumatera worth Rp70.000. The targeted marketing areas are Jambi province, $65 \%$ and $35 \%$ outside Jambi \& Palembang, Pekanbaru, Jakarta, West Java, Aceh, Padang, East Java, Lombok, and Papua. Buyers here act as retailers who sell to consumers directly or retailers.

In order to develop a business, it is necessary to have a study of marketing strategies that are introduced to the marketing mix (marketing mix). A review of the marketing mix is examined from 4 aspects, namely a) products, b) prices, c) distribution, d) promotions.

\section{Products}

The business of ICN Kerinci coffee perfume industry offers air freshener and car freshener in the form of "coffee perfume," which is packaged in bags made of knitted yarn and coffee oil packaged in bottles, measuring 45 grams in weight with the trademark of "ICN Kerinci Coffee Perfume."

\section{Price}

Determination of the selling price of ICN Kerinci coffee perfume products is based on the production costs incurred and attention to market prices, particularly the price of Bali Coffee Perfume as a competitor. The selling price of the original coffee perfume is Rp. 22,000 / package weighing 45 grams, while for coffee, perfume + coffee oil packaging is sold at Rp. 35,000 / package.

\section{Distribution}

Determination of distribution channels in selling a product will determine the success of a business. Business owners use a selective distribution approach to maintain the quality of their products so that in the event of complaints from consumers, the business owner can reprimand the distributor directly. Besides the benefits above, this method can also save marketing costs. 


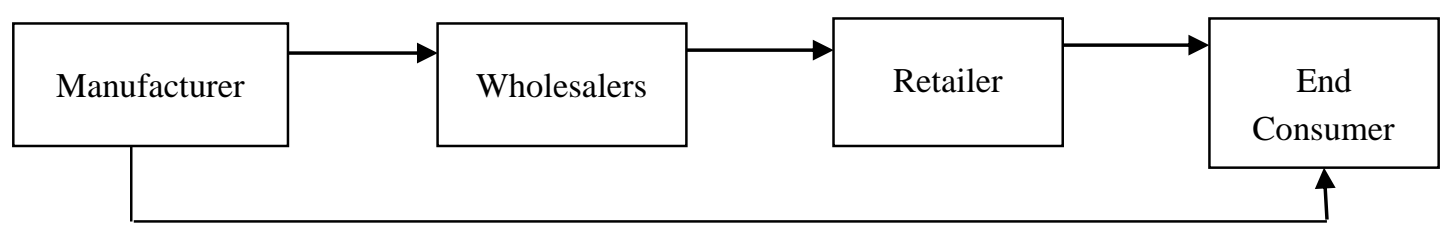

Channel $2(2 \%)$

Figure 1. Distribution Channel Scheme of ICN Kerinci Coffee Perfume Industry 2019.

The details of the distribution channel scheme of the ICN Kerinci coffee perfume industry can be explained in Figure 1.

\section{Promotion}

Promotion is the activity of communicating and introducing a product to the target market. In promoting the products, business owners utilize consumers who are loyal to this product because loyal consumers are considered, to be honest informants about products. This means that other consumers will know the products by word of mouth that can demonstrate the superiority of the product accurately.

Business owners also carry out information through print media such as the distribution of brochures, electronic media such as TV and social media through Facebook, Instagram, and WhatsApp (WA), so that the target market reaches regions outside West Sumatra and Jambi, such as Aceh, Medan, Palembang, Pekanbaru, Bangka Belitung, Lampung, Malang, Sidoarjo, Jakarta,
Bandung, Purwokerto, West Kalimantan, South Kalimantan, Lombok, Bau-Bau, Makassar and Papua. The largest turnover is for the regions of West Sumatra and Jambi (65\%) and the other 35\%.

\section{Analysis of Profit and Loss}

Net profit can be obtained from the reduction of all revenues with all costs. Revenue is also known as sales revenue. Sales revenue for the period June 2019 August 2019 is presented in table 1.

From Table 1, it can be explained that the revenues from the sale of coffee perfume products during June 2019 - August 2019 Rp1.262.850.000 worth of sales of 36,800 copies per original perfumes and 12,950 perfume coffee + coffee oil. The increase in revenue in August was due to an increase in the number of requests and also the expansion of marketing areas to Eastern Indonesia such as Kalimantan, Sulawesi, and Papua.

\section{Cost}

Tabel 1. Revenue from ICN Kerinci coffee perfume agroindustry sales from June 2019 - August 2019 period.

\begin{tabular}{lllll}
\hline Month & Production & Selling & Price (Rp) & Selling Income (Rp) \\
\hline June & Original:11.000 & 11.000 & 22.000 & 242.000 .000 \\
& Package: 4.000 & 4.000 & 35.000 & 140.000 .000 \\
\multirow{3}{*}{ July } & Original:11.000 & 11.000 & 22.000 & 382.000 .000 \\
& Package: 4.000 & 4.000 & 35.000 & 140.000 .000 \\
& & & & 382.000 .000 \\
August & Original:15.000 & 14.800 & 22.000 & 325.600 .000 \\
& Package 5.000 & 4.450 & 35.000 & 173.250 .000 \\
& & & & 498.850 .000 \\
Total & Original:7.000 & 36.800 & 22.000 & 809.600 .000 \\
& Package 13.000 & 12.950 & 35.000 & 453.250 .000 \\
\hline
\end{tabular}


Costs incurred to calculate profit or loss from ICN Kerinci coffee perfume business activities use the variable costing method in which the cost components are distinguished from fixed costs and variable costs. total costs incurred during the accounting period June 2019 - August 2019 valued at Rp 438,789,000, consisting of fixed costs of 27,598,128 (6.27\%) and variable costs of $411,289,000(93.73 \%)$ with production of 37,400 pcs original coffee perfume $(73.33 \%)$ and coffee + coffee perfume 13,000 pcs $(26.67 \%)$. The biggest variable cost component is for purchasing green bean coffee and oil coffee raw materials as supporting materials with a value of Rp. 176,240,000 (40.16\%). The high cost of purchasing raw materials shows that the coffee perfume agroindustry business can be used as an opportunity to develop a plantation business that is managed $100 \%$ by the community in the research location.

\section{The profits of the ICN Kerinci coffee perfume industry}

Business activity is said to be successful if the business makes a profit where the value of this profit is obtained from the difference between all revenues minus all costs. Profit is the main goal of business activities. Business profits of the ICN Kerinci coffee perfume industry can be seen in Table 2 .

Table 2. Income Report of ICN Kerinci Coffee Perfume Period June 2019 - August 2019

\begin{tabular}{lll}
\hline No & Information & Total $(\mathrm{Rp})$ \\
\hline 1 & Net Revenue & 1.262 .850 .000 \\
2 & Biaya variabel & 411.289 .000 \\
3 & Laba kontribusi & 851.561 .000 \\
4 & Biaya tetap & 27.598 .128 \\
5 & Laba sebelum pajak & 823.962 .872 \\
6 & PPH (1\%) & 8.239 .629 \\
7 & Laba bersih & 815.723 .243 \\
\hline
\end{tabular}

From Table 2 above, it can be analyzed that during the period of June 2019 - August 2019, the business had made a profit of $\mathrm{Rp} 815,723,243$ with a profitability of $186 \%$, which meant the business was very profitable and provided a very large opportunity to be developed, both for the industry itself and farmers coffee.

\section{Break Even Point}

In this breakeven point analysis, costs are grouped into variable costs and fixed costs. The elements needed in this calculation are total fixed costs, total variable costs, variable costs per unit, production volumes, and selling prices.

The breakeven condition (BEP) experienced by ICN Kerinci perfume coffee agroindustry achieves a sale quantity of 1453 pcs/pack and a sales value of Rp31.950.911 for the original type. While for the type of packing type, the breakeven quantity obtained when selling products of 273 packages with a sales value of Rp. 9,560,837. From the above assessment, it turns out that the business has sold above the breakeven point of quantity, and even sales (rupiah) means the business is in a profit position.

\section{CONCLUSIONS AND RECOMMENDATIONS}

\section{Conclusion}

Based on the results of research on the analysis of the Ilham Creative Preneur Kerinci (ICN Kerinci) Coffee Ilham Creative Perfume business in Kemantan Village, East Air Hangat District, Kerinci Regency, Jambi Province, it can be concluded:

1. The ICN Kerinci coffee perfume business was founded initially on a noble desire to improve the welfare of coffee farmers in the area of the business owner, Mr. Gunaryadi. The low price of random coffee (cherry) set by traders is $\mathrm{Rp8}, 000$ / kg, causing farmers not to be stimulated to manage their businesses. In addition to the low coffee price factor, the desire to open a coffee agroindustry business is also driven by the desire to increase family income.

His 19-year experience working for an American company engaged in the production of essential oils was the key to his success in business. At the time of the study, the business has already employed ten employees and collaborating with 20 farmers who manage 25 ha of coffee plantations as business partners in order to supply raw materials of coffee perfume so that farmers can secure markets and have better prices (in current research, coffee prices reached $\mathrm{Rp} 15,000 / \mathrm{kg}$ in the form of cherry, or Rp32,000 - Rp45,000 in the form of green bean). 
2. During the accounting period of June 2019 August 2019, the ICN Kerinci coffee perfume agroindustry has gained a business profit (EAT) of Rp815,723,234 or an average of Rp271,907,748 per month. The breakeven point (BEP) is obtained at the breakeven quantity of 1,453 pcs and the breakeven sale of Rp31,950,911 for the original sale. As for package sales (original + coffee oil), breakeven quantity was reached when 273 packages or BEP sales were valued at $\mathrm{Rp} 9,560,837$ and profitability was $186 \%$. Results pen edition indicate that the ICN Kerinci coffee perfume business is very feasible.

\section{Suggestions}

From the research results, it can be suggested the following activities:

1. Business owner is expected to expand the market, especially for Eastern Indonesia, given the new market opportunities to enter $35 \%$.
2. Enhancing cooperation with partner farmers, in order to ensure the security of supply of raw materials as well as giving the green bean price is based on the results of sorting and grading so as to further stimulate farmers to improve the quality of the products they produce green bean.

\section{REFERENCES}

Lestari, D. A. (2013). Peranan Industri Kopi dalam Perekonomian Indonesia: Suatu Analisis Input Output (IO). Malang: Universitas Brawijaya.

Romdhon , M. M., Andani , A., \& Ayu , A. M. (2018). Sensitivitas Kelayakan Finansial Pengolahan Kopi Bubuk. Agrisep, 31-38. 